\title{
Is small really beautiful? A review of the concept of niches in innovation
}

This article reviews the concept of innovation niches through three categories: strategic niche management (SNM), specialised markets and niches formed as a technology declines. In the literature, innovation niches generate interest from both innovation and marketing perspectives. This review focuses predominately on the former from which the niche types have been adopted and analysed. Mostly, contributions since 1980 have been included, representing the period of academic interest in innovative small firms, while both temporal and locational filters were applied to the study. It is noted that SNM has been proposed as a means to protect potentially useful innovations from full market competition, while specialist niches supply technologies to few customers in more stable environments. Incumbent technologies at the stage of decline may also retreat to niches where they can still remain competitive. Finally, it is suggested that further research on innovation niches would extend our understanding of technology dynamics.

Keywords: Innovation niches; strategic niche management; specialised technologies; technology decline 


\section{Introduction}

The concept of niches has been used in innovation studies in a number of different ways. However, the underlying idea of a niche, implying a product, process or service with a small market, has not been subject to much broad analysis in terms of identifying constituent attributes. This article reviews the literature on niches from an innovation perspective. It identifies how the concept of niches has been appropriated by innovation studies in general and the type of technologies that fill such small markets. This review can, therefore, contribute to previous surveys of this academic area (see for example Hoffman et al. 1998; Smith and Raven 2012; Sengers et.al. 2016). One contributory issue concerns niche definition. From the marketing perspective, a niche has a number of identifiable characteristics (Dalgic and Leeuw 1994). The innovation literature, however, draws a distinction between perspectives that understand technological niches as dynamic and those that focus on more stable, persistent situations. This article reviews academic literature on innovation niches, constructed from literature searches on a number of keywords, building on the initial search for 'innovation and technology niches'. The initial results indicated that sources would be found in three categories, Strategic Niche Management (SNM), small technology-based firms and retreating, mature technologies. The keyword search was instrumental in developing understanding of the characteristics of each category.

This article is structured as follows. Section 1 discusses the broad methodological approach adopted in conducting the review. This is followed by sections covering three types of innovation niches: 
Section 2 considers niches formed at the beginning of a new technology cycle, reviewing the strategic niche management (SNM) literature. This suggests actions that can be used to protect and encourage the survival of new technologies.

Section 3 considers the activities of technology-based firms that are niche actors. These firms are highly specialised, and have innovation focussed survival strategies, often supplying more than one niche.

Section 4 focuses on niches developed by incumbent firms, where a mature technology has been replaced by a disruptive innovation. The technology retreats strategically to a niche with characteristics that favour its survival.

\subsection{Method}

The review was constructed based on three key questions relating to current understanding of innovation niches:

1. What aspects of niche innovations are covered by the existing literature?

2. How are innovation niches characterised by the literature and how narrowly are the categories delineated?

3. Can gaps in the data be identified, and if so, what new research questions emerge from the analysis?

The review was carried out after an initial screening of sources on the keywords 'innovation niches', 'technology niches' which was used to scope the extent of conceptual diversity. A temporal filter was not used at this screening stage. This revealed texts mainly from the innovation literature and some from marketing with a focus on innovation processes. This initial search suggested that concentrating on the 
three categories adopted in this article would most accurately reflect current conceptualisations of innovation niches.

Filters were then utilised to refine the search and to form boundaries to the three categories. Both conceptual and case study texts were reviewed as many studies in the innovation niches literature use cases as a means to investigate more conceptual issues. Keyword searches were carried out on a number of digital databases (Academic Search Premier, Google Scholar, Science Direct and Scopus). The results formed the initial basis for the innovation niche categories, while coding of whole texts by subject delivered the sub-topics for each category. It should be noted that these sub-divisions are specific to each section, although the method of identification was the same for each one. Besides the keyword searches, additional sources were identified by looking at the reference lists and citations of the articles. Filters were applied, excluding marketing articles that were not concerned with innovation niches and articles focusing on innovation clusters. A temporal filter, (excluding texts prior to 1980), was adopted, in part as an impressionistic analysis that study of innovation niches has increased dramatically since that decade. The authors acknowledge the limitations that arise from such boundary setting decisions. Results of the search are summarised in the following sections.

\subsection{Strategic niche management and emergent niches}

This section reviews the concept of Strategic Niche Management (SNM) from the perspective of Transitions Studies (Kemp et. al. 1998). Here, a technology niche describes an innovation at an early stage of development with limited scope. In addition, it has a certain distance, seclusion, difference or protection from environmental, political, social and/or economic conditions considered to be standard in a particular 
system. There are at least three recognised categories of niches, namely technological niches (Van de Belt and Rip 2004; Raven 2006; Geels and Raven 2006; Coenen et al. 2010; Smith and Raven 2012); market niches (Levinthal 1998; Raven 2006; Smith and Raven 2012); and policy niches (Ieromonachou et al. 2004). Raven (2006) mentions a fourth category of R\&D niches. Technological and market niches are delineated by the nature of the innovation: technological/policy and market niches represent different stages of development along a transition trajectory (Geels and Schot 2007; Schot and Geels 2008). Raven (2006) suggests R\&D niches are at distinct developmental stage. Although the role, function and processes associated with niches have been expanded over time, the main protective function of the niche has remained virtually unchanged (Schot and Rip 1996; Levinthal 1998; Schot 1998; Kemp et al. 1998).

\subsection{The concept of 'technology protection'}

Initially, the SNM concept was aligned with the idea that emergent radical innovations require protection from market forces to mature (Kemp et al. 1998; Schot 1998; Geels 2002). A protected space would mitigate barriers to development, such as economic inefficiencies, and technological lock-in (Markard et al. 2012; Unruh 2000). Protective strategies would enable technologies to overcome initial weaknesses (Smith and Raven 2012). The initial notion of a technological niche was a protected space which acts as an incubator for a fledgling technology, granted through policy measures and financial support (Kemp et al. 1998; Raven 2006; Geels and Raven 2006). Financial subsidy is a main protective measure as suggested by Raven (2006, 2007a), Geels and Raven (2006), Van der Laak et al. (2007) and Smith and Raven (2012). There is a strong focus on the experimental nature of technological niches (Schot and Rip 1996; Kemp et al. 1998; Geels 2002; Ieromonachou et al. 2004; Raven 2006; Caniëls and Romijn 2008a). The niche technology has a specific application domain and is supported by willing 
actors, specific locations and different market selection pressures (Levinthal 1998; Schot 1998; Raven 2006; Smith 2007; Schot and Geels 2008; Van der Laak et al. 2007). In addition, the setting can be experimental, such as pilot projects or laboratory spaces (Schot and Rip 1996) or through niche accumulation where the technology is used in several subsequent applications (Raven2006, 2007b; Van der Laak et al. 2007). Future market conditions are determined in a co-evolutionary process involving market structures and innovation proponents (Van der Laak et al. 2007; Caniëls and Romijn 2008b).

In SNM, niches created by immature technologies need opportunity and guidance to evolve usefully (Raven and Geels 2010). Learning, with a special focus on second-order and deep learning processes, is the most desirable outcome (Geels and Raven 2006; Schot and Rip 1996; Ieromonachou et al. 2004). These processes co-manifest as the articulation of joint expectations, carried through forming and strengthening actor networks (Kemp et al. 1998; Raven 2006). The technological niche co-develops with associated knowledge, comprising shared rules, heuristics, expectations, global models and local experiments (Geels and Raven 2006; Raven and Geels 2010). Ultimately, the emerging trajectory might evolve into a market niche (Hoogma et al. 2002; Schot and Geels 2008). This evolutionary process takes time, varying between two and five decades (Coenen et al. 2010; Raven and Geels 2010). Success is not guaranteed, with niche technologies prone to disruptions at any stage of the process (Raven and Verbong 2004; Geels and Raven 2006; Verbong et al. 2010; Verhees et al. 2013; Smith et al. 2014).

Summarizing the above, a 'technological niche' for SNM could be described as a 
protected space centred on a radical, possibly sustainable innovation focusing on protecting the innovative technology by the means of public and/or private financial subventions and public policies while at the same time providing an arena for undertaking localized experiments facilitating learning effects, especially second-order learning among niche proponents, early users and innovators.

A market for the technology is formed through expansion of the strategic niche. From this position, the innovation might develop the capacity to disrupt and transform an incumbent regime, (Geels and Schot 2007; Schot and Geels 2008). Finally, the protective functions are expected to be temporary measures, to ensure survival of the innovation in its early stages (Kemp et al. 1998; Geels and Raven 2006; Raven 2007). After reaching stability niche protection should be deconstructed in a controlled manner (Kemp et al. 1998; Smith and Raven 2012). SNM literature includes a number of case studies which have been used by commentators to explore the micro-dynamics of specific support mechanisms at work in situ. Three dominant themes can be identified: historical cases, sustainable technologies, and a broader category concerned with practical application of protective practices (see Table 1 in the appendix). Study of the protective function of niche management is concerned with elucidating the dynamics of the processes as the technology moves from niche to mainstream. However, some technologies are developed specifically for niche applications and there is a literature which considers the dynamics of these more stable niches. The following section reviews the literature on these specialised innovation niches.

\subsection{Technology-based firms and specialist niches}

A specialist niche is predominately filled by small firm innovation, although a few commentators have also discussed the role of large firms (Debruyne and Reibstein 
2005; Hardman et al. 2015, see also Dobrev et al. 2003; Utterback and Acee 2005). Innovative small firms can specialise in supplying specific sectors (Hamlin et al. 2012; Pavitt 1990). New technology-based firms' (NTBF) have been identified as such niche innovators (e.g. in books by During et al. 2001; Oakey et al. 2013). They develop specialist technologies and often collaborate with other firms (Pavitt 1990; Dickson et al. 1997; Harris et al. 2000). Various commentators have suggested taxonomies of NTBF. These typically divide into scientist or engineer owned enterprises, such as high technology start-ups; and firms innovating as suppliers or sub-contractors (Tidd et al. 2001; Dickson et al. 1999; Jones-Evans and Steward 1995; Rappert 1997). For these firms, their potential for innovation provides a competitive edge in the search for a stable niche (Peters and Coles 2010). The requirement for such specialist technologies has been identified in a wide range of niche markets.

\subsection{The nature of specialist niches}

Different niche types have been identified, including:

(1) Those formed from the presence of disruptive technologies in an existing industry (Debruyne and Reibstein 2005; Hardman et al. 2015)

(2) Those representing geographical specialisation, including the role of innovating firms to regional regeneration (Sidibé et al. 2012; Foray 2014; Simmie 2012; Komninos et al. 2014, Landabaso 2014; Smith et al. 1993).

(3) New markets arising from complementary technologies developed for existing niches (Singh and Prasad 2014)

(4) Micro-niches created through agile manufacturing and e-commerce (Fauska et al. 2014). 
(5) Technology users acting as niche innovators (Haefiger et al. 2010; Chandra and Coviello 2010; Smith 2012).

The positive characteristics of specialist niches include close relationships between customer and supplier (Keegan et al. 1992; Hooley and Saunders 1993; Fauska et al. 2014; Kotler 2003; Dalgic and Leeuw 1994; Dalgic 2011). Others emphasise the development of products or services for a group of homogenous customers (Kotler 1989; Toften and Hammervoll 2009), although Andrews and DeVault (2009) point out that such homogeneity can become a barrier to market development.

Fauska et al. (2014) perceive increasing specialisation as a benefit to increasingly small markets through use of agile manufacturing and e-commerce. Such 'narrow and deep' specialisation can depend on retaining customer loyalty (Pepall 1992, Simon 1996). Friedman et al. (2007) consider micro-niches created by 'hyper-differentiated products', while Srinivasan et al. (2006) discuss factors that create multiple niches in a new industrial sector. They identify 'tight appropriability', including factors such as comprehensive patenting, secrecy and technology complexity as factors in niche fragmentation.

\subsection{Balancing innovation and opportunity}

The need to focus on highly defined customer needs, innovation opportunities and threat of competition can provide a strategic tension for the small firm (Toften and Hammervoll 2010; Fergusson 1988; Ford et al. 2014; Debruyne and Reibstein 2005; Dalgic 2011; Hezar et al. 2006; Bantel 1997; Delaney,1995; Jain2005). Hamlin et al. (2012) consider firm survival, suggesting that strategic search for new niches needs to be on-going (see also Genus and Coles 2006, McGrath, 1995). For Hunt (2013) and Corrocher and Guerzoni (2015), small firms survive as specialist innovators supplying 
parts, complementary knowledge and design modifications to established and emerging sectors.

In the development of new niche opportunities, both Park (2005) and Berkhout et al. (2011) suggest the process requires a complex interaction between entrepreneurial knowledge, firm competence and technological potential. Stritar and Drnovšek (2016) and Breschi et al. (2014) also stress the role of knowledge (see also Marvel and Droege, 2010). Entrepreneurial learning and strategic positioning have both been identified as an aspect of successes in addressing new niche opportunities (Coles and Jones 2000; Dickson et al. 1996; Gaudes 2004; Gruber et al. 2008). In the Malaysian biotechnology sector, for example, interaction between business, social and political factors has shaped the niche (Said et al. 2014). Similar outcomes were noted by Morone et al. (2015) in a study of technological niches in Italian bio-plastics. Corrocher and Guerzoni (2015) report on one firm's strategic success in developing specialised technologies for the medical sector, observing the benefits of supplying more than one niche (see also Lai et al. 2011; De-Fu et al., 2011).

A number of studies have shown the benefits of firm networks in developing technological niches (Dickson et al. 1990; Dodgson 1993; Young and Vonortas 2014). Small firms may develop a number of strategic alliances, in some cases internationally to exploit specialist markets (Ahern 1993; Coles et al. 2003; Conway, 1995; Georghiou and Barker, 1993; Harris 1999, Harris et al. 2000; Laranja1998). Other issues relating to network position affect success including both size and type of network (Beesley and Rothwell, 1987; Hayter et al. 2003; Wang and Chen 2016). Marinova and Balaguer (2009) on the other hand find strength and size of heterogeneous networks may affect the speed of niche growth. Some firms mitigate risk by becoming sole suppliers through specialist competences (Gray and Gonsalves2002; Namba 2007; Simba 2015). 
Continued success may result from a strategy of continuous innovation rather than on firm growth. Niche innovators do not need protective measure identified for SNM, but they do use strategic approaches in their business dealings. Embedding their firms in heterogeneous networks is a risk minimising strategy. However, there is little academic study relating to how these types of specialist niches persist or develop over time. The next section reflects on these issues, considering niches, which emerge as established technologies retreat in the face of competition.

\subsection{Technological decline and niche creation}

This section focuses on retreat of incumbent technologies to a niche, usually as a result of competitive pressures. Repositioning activities, such as the sailing ship effect, have been subjected to re-examination (Howells 2002; deLiso and Filatrella 2008; Mendonça 2013). Furthermore, the longevity of technologies such as optical lithography suggests that the pace of decline is hard to predict (Henderson 1995, see also Shove 2012). Analysis of strategic choices demonstrates a complex interplay between incumbent and disruptive technologies.

\subsection{Managing technology decline: retreat, survival and revitalisation}

Demand in a particular industry can decrease at varying rates (Rudie Harrigan, 1980). Outcomes could be obsolescence, market shrinkage to a niche or reversal through product revitalisation. Incumbents can react to disruptive technologies by acceptance, incorporation, or by trying to defeat it. Firms who persevere with the incumbent technology may choose the following strategies (Adner and Snow 2010 a\& b):

(1) Accelerate the performance of the incumbent technology in their current market (the racing strategy)

(2) Retreating to a niche position in the current market (the retreat strategy) 
(3) Repositioning the old technologies to new applications in a different target market

Improving performance of the incumbent technology in the face of competition (the racing strategy), does not always prevent its final displacement. Alternatively, firms can retreat to a niche where the old technology holds competitive advantage. Repositioning the old technology can also lead to the emergence of a niche (Adner and Snow 2010b).

Product revitalisation enables the survival of incumbent technologies after the introduction of radical competitors. Schiavone (2014) notes this is often achieved by means of the sailing ship effect but argues that revitalisation can also occur from introduction of products, which benefit from the emerging technology. In the case of analogue cameras, film scanners, which utilised the disruptive technology of digital imaging to digitise analogue photographs, have enabled the continuing use of analogue photography. Abernathy et al. (1983) and Klepper (1997) also argue that emergence of new technologies can obstruct transition to the decline stage. Schiavone's $(2013,2014)$ concept of vintage innovation illustrates how user groups including radio amateurs arcade videogame players and DJs extend the life of their preferred products. Therefore, a declining technology can survive in a niche and firms can strategically manage this decline. Snow's (2004) research suggests that there are complementarities between the incumbent and emergent technologies (see also Eggers 2012). Rudie Harrigan's (1980) study identifies the following conditions that enable firms to persevere in a declining industry:

- Continuing demand for the industry's products by a few loyal customers.

- The incumbents' products do not suffer cost disadvantages

- Price wars are avoided 
- Firms benefit from a strong brand name.

Technology reverse is another mechanism that supports incumbent technologies as they benefit from some characteristics of the emerging technology, while product revitalisation requires market niches where the incumbent technology holds symbolic and social significance (Schiavone 2014). The persistence of analogue photography is partly explained by the reluctance of users to switch to digital if they have invested in their photography skills (Runde et al. 2009). The case of the LP provides another example of a technology with symbolic, social and aesthetic significance that has been revitalised within a niche (Nokelainen and Dedehayir 2015) Nostalgia and dissatisfaction with the music industry has also enabled revitalisation of the LP (ibid.). Adner and Snow (2010 a\&b) argue that the survival of the incumbent technology depends on the heterogeneity of demand where there are market segments with varied trade-offs between price and performance. The retreat strategy is likely to be successful when customer segments differ significantly on evaluation of products and technologies. Case studies of technologies, which have been identified as declining to a niche are summarised in Table 2 (in the appendix).

\subsection{The sailing ship effect and technological survival}

The sailing ship effect was coined by Ward (1967) to describe continual innovation in the incumbent technology after an emerging technology has entered the market (named after Gilfillan's (1935) study on sailing ships). The effect can account for success of the racing strategy identified by Adner and Snow (2010a). Improvements in the performance of the incumbent technology can enable its survival as it retreats, the phenomenon is relevant to understanding emergence of niches following technology decline. Although, significant improvements in technology performance may occur at 
the decline stage, their cause is not clear. Howells (2002) notes that the sailing ship effect was identified retrospectively but the threat from the emerging technology was not a pre-requisite for the performance improvements of the incumbent. However, evidence from the automotive sector suggests that a sailing ship effect occurs as the industry responds to electro-mobility (Sick et al. 2016). However, the incumbent technology can keep attracting investment even if it is technically inferior (Chari and Hopenhayn 1991). The efficiency growth achieved by an incumbent technology in response to new technological threats has also been labelled the "last gasp" (Snow 2004). Referring to the competition between carburettors and electronic fuel injection (EFI) he proposes two mechanisms that can explain the "last gasp": a) the displacement effect: as the incumbent technology loses ground it is first pushed out of the less efficient applications. Hence, it appears more efficient b) the technological spillover effect where components from the new technology improve the performance of the incumbent. Finally, new firms may enter a market using (Agrifoglio et al. 2016) demonstrated in the case of an attempt to revive Polaroid cameras. In conclusion, the actual contribution of the sailing ship effect to technology retreat still needs clarification.

\subsection{Discussion}

This article reviews literature pertaining to development of technologies niches although there is no general, quantifiable definition which precisely explains the term. Niche innovation literature is disaggregated between the three prominent themes identified in this article, SNM, specialist niches and those create by declining technologies. In SNM, the focus is on novel technologies at the start of the lifecycle which have the potential to grow to system wide destabilising technologies. Technology 
-based firms are subject to market forces, and are likely to remain small and specialised. Innovators in declining technologies are faced with a market reducing in size, innovating to extend the reach of their technology.

This article has attempted to draw together these divergent lines of study. This aim has been to clarify and further elucidate the role of niche innovation plays as part of the overall arena of technology development activities. 'Niches' are common to all three categories, although both within and between each category it is a highly variable and heterogeneous concept. In addition, these categories appear independently in the literature and address quite different aspects of niche activity. Despite the analytical distinction between the categories, it is possible to suggest some relationships between them, for example, SNM and mature technologies are linked through the technology lifecycle, as one niche develops an old technology retreats. Both small firm and mature technology niches share exposure to market forces, while niches in SNM which fail to grow could potentially become an example of specialist niches. However, development of these insights is somewhat beyond the scope of this article and requires more data to pursue such theoretical insights. Some general themes, common to all three categories have been identified:

1. A niche represents a bounded space for innovation. Some niche technologies address the needs of small markets, while for SNM a niche can be defined in the absence of explicit customers being developed by alternative arrangements.

2. Small markets present challenges to innovating firms particularly in respect of their opportunity for long term survival and financial return. This influences the potential for continued innovation 
3. Niche technologies perform a function in a limited environment. Innovators continually need to maintain correspondence between niche requirements and technological capability. They are, therefore, vulnerable to failure.

4. A consequence is that innovators in all three categories need to be engaged in continual strategic positioning to keep innovation and opportunity aligned. For SNM technologies are strategically protected from potential market-technology misfit. Specialist niches depend on knowledge gathering and networking activities of entrepreneurs to align technology and market, while mature technologies are successful through strategic repositioning.

It is clear, then, that understanding the concept of niches as small spaces where specific technologies can survive requires some further work. This will provide greater clarification of the process and dynamic interactions that are creating situations for successful continuation of niche-level technologies. All three of the niche technology categories reviewed here have potential for further study, although the initial programme would not necessarily bring the disparate stands closer together. Within SNM, one issue would be to further investigate the relationship between technological and market niches. A second would investigate niche failures, following the work of Raven and Verbong (2004) and Verbong et al. (2010). One final, cross-theory pathway would be to review the variability of innovation niche concepts used across the different schools of thought, search for a possible encompassing niche definition. This approach might be extended by the study of radical, sustainable innovation niches and their required protection and support. Specialised technology- based niches exhibit very different characteristics. They are more likely to be stable or slowly changing over a long period of time. In addition, the discussion here has identified the pro-active agency 
of the technology entrepreneur as a key success factor. However, there are issues arising in relation to aspects such as the dynamics of niche development, identification of niche characteristics, refining niche typologies which call for further study. There is a limited amount of information available on declining technologies, and on the process of retreat, in particular the speed of niche formation and their stabilisation processes. In particular, the cultural meanings and values relating to the declining technology and its possible revitalisation can be elucidated further..

This review has examined how the processes of niche development take place at different stages of the technology lifecycle; effective niches do not necessarily rely on growth but depend on matching particular technologies to market segments where they may hold advantages.

\subsection{Conclusion}

This article has presented a review of texts relating to the concept of innovation niches. The study has been limited by the need to manage the extent of the literature surveyed, which led to setting boundaries which excluded articles from marketing and other neighbouring disciplines, and to some temporal limitation. In addition, the review focuses on innovation by individual firms, avoiding clustering and other locational issues. The review was compiled and analysed using typologies which emerged from the existing literature on innovation niches. In particular the article has:

- identified and surveyed the literature relating to innovation niches

- proposed a taxonomy through which different types of niche innovation can be analysed

- revealed areas where information is lacking and require further research 
While acknowledging that the concept of niches is utilised by different authors in a rather dispersed manner, it is suggested here that further research and reflection on the concept of innovation niches would benefit our understanding of technological dynamics more generally.

\section{References}

Abernathy, W., K. B. Clark and A. M., Kantrow, 1983. Industrial Renaissance: Producing a Competitive Future for America. New York: Basic Books.

Adamides, E. D., and Y. Mouzakitis, 2009. "Industrial ecosystems as technological niches." Journal of Cleaner Production 17 (2): 172-180.

Adner, R., and D. Snow. 2010a. "Old technology responses to new technology threats: demand heterogeneity and technology retreats." Industrial \& Corporate Change 19 (5): $1-21$.

Adner, R., and D. Snow. 2010b. "Bold retreat.” Harvard Business Review 88 (2): 76-81. Agrifoglio, R., F. Schiavone and C. Metallo. 2016. "Investigating the Sailing Ship Effect as Newcomers' Strategic Reaction to Technological Change." In Empowering Organizations, edited by T. Torre, A. M. Alessio and R. Spinelli, 39-49. Basel: Springer International Publishing.

Ahern, R. 1993. "Implications for strategic alliances for small R \& D intensive firms." Environment and Planning A 25 (10): 1511-1526.

Andrews, C., and D. DeVault. 2009. "Green niche market development: a model with heterogeneous agents." Journal of Industrial Ecology 13 (2): 326-345.

Bakker, S., H. van Lente, and R. Engels. 2012. "Competition in a technological niche: the cars of the future." Technology Analysis and Strategic Management 24 (5): 421-434. Bantel K. A. 1997. "High tech, high performance: The synergy of niche strategy and planning focus in technological entrepreneurial firms." Washington: Washington DC Working Papers. 
Beesley, M., and R. Rothwell. 1987. "Small Firm Linkages in the United Kingdom.” In Innovation, Adaptation and Growth, edited by R. Rothwell and J. Bessant. Oxford: Elsevier.

Berkhout, A.J., D. Hartmann, and P. Trott. 2011. "The role of entrepreneurship in innovation." International Journal of Entrepreneurship and Innovation Management 14 (1): 60-74.

Breschi, S., C. Lenzi, F. Malerba, and M. L. Mancusi. 2014. "Knowledge-intensive entrepreneurship: sectoral patterns in a sample of European high-tech firms." Technology Analysis and Strategic Management 26 (7): 751-764.

Burnouf, T. 2006. "Plasma proteins: Unique biopharmaceuticals-Unique economics." Pharmaceuticals Policy and Law 7: 209-218.

Caniëls, M.C.J., and H. A. Romijn. 2008a. "Actor networks in Strategic Niche Management: Insights from social network theory." Futures 40 (7): 613-629.

Caniëls, M.C.J., and H.A. Romijn. 2008b. "Strategic niche management: towards a policy tool for sustainable development." Technology Analysis \& Strategic Management 20 (2): 245-266.

Chalasani, S., and D. Shani. 1992. "Exploiting niches using relationship marketing." Journal of Consumer Marketing 9 (3): 33-42.

Chandra, Y., and N. Coviello. 2010. "Broadening the concept of international entrepreneurship: Consumers as International Entrepreneurs." Journal of World Business 45 (3): 228-236.

Chari, V.V., and H. Hopenhayn. 1991. "Vintage human capital, growth and the diffusion of new technology." Journal of Political Economy 99 (6): 1142-1165.

Christensen, C. 1997. The Innovator's Dilemma: How New Technologies Cause Great Firms to Fail. Brighton: Harvard Business School Press.

Coenen, L., R. Raven, and G. Veerbong. 2010. "Local niche experimentation in energy transitions: A theoretical and empirical exploration of proximity advantages and disadvantages." Technology in Society 32 (4): 295-302.

Coles, A.M., and A. Jones. 2000. "From lifelong learning to organisational change for small firm entrepreneurs." Widening Participation and Lifelong Learning 2 (1): 24-31. 
Coles, A. M., L. Harris, andK. Dickson. 2003. "Testing goodwill: conflict and cooperation in new product development networks." International Journal of Technology Management 25 (1/2): 51-64.

Conway, S. 1995. "Informal boundary spanning communications and the innovation process: an empirical review." Technology Analysis and Strategic Management 7 (3): 327-343.

Corrocher, N., and M. Guerzoni. 2015. "Post-entry product introduction: who explores new niches?" Industry and Innovation 22 (1): 18-36.

Dalgic, T., ed. 2011. Handbook of Niche Marketing: Principles and Practice. Oxford: Haworth Press/Routledge.

Dalgic, T., and M. Leeuw. 1994. "Niche marketing revisited: concept, applications and some European cases.” European Journal of Marketing 28 (4): 39-55.

Debruyne, M., and D. J. Reibstein. 2005. "Competitor see competitor do -incumbent entry in new market niches." Marketing Science 24 (1): 55-66.

De-Fu, C., W. Yong-Zhi, and L. Shi-Ming. 2011. "The evolutionary path of technological capability and the choice of niche market: A longitudinal research from QOK Corporation." Proceedings of the International Conference on E-Business and EGovernment, ICEE2011.

Delaney, J. 1995. "Minding your own niche business.” Nations Business 85 (5): 56-58.

Dickson, K., A. M. Coles, and H. Lawton Smith. 1996. "Learning issues in successful long term, inter-firm research collaboration.” Strategic Change 6 (5): 273-283.

Dickson, K., A. M. Coles, and H. Lawton Smith. 1997. "Staying the course: strategic collaboration for small, high-technology firms." Small Business and Enterprise Development 4 (1): 13-20.

Dickson, K., A. M. Coles, and H. Lawton Smith. 1999. "Science in the Market Place: The Role of the Scientific Entrepreneur", In New Technology Based Firms in the '90s, edited by W. During and R. Oakey, Vol. 4, 27-37. Amsterdam: Elsevier.

Dickson, K., H. Lawton Smith, and S. Smith. 1990. “The Small Firm Perspective on Interfirm Collaboration." In The Cooperation Phenomenon, edited by D. O'Doherty. London: Graham and Trotman, London, 
Dobrev, S.D., T. Y. Kim, and G. R. Carroll. 2003. "Shifting gears, shifting niches: organizational inertia and change in the evolution of the U.S. automobile industry, 1885-1981.” Organisation Science 14 (3): 264-282.

Dodgson, M. 1993. Technological Collaboration in Industry: Strategy, Policy and Internationalism in Innovation. London: Routledge.

During, W.,R. Oakey, and S. Kauser, eds. 2001. New Technology Based Firms in the New Millenium 1.Oxford: Pergamon Press.

Eggers, J. P. 2012. "Falling flat, failed technologies and investment under uncertainty." Administrative Science Quarterly 57 (1): 47-80.

Fauska, P., N. Kryvinska, and C. Strauss. 2014. „Agile management of complex goods \& services bundles for B2B: e-commerce by global narrow-specialized companies." Global Journal of Flexible Systems Management 15 (1): 5-23.

Fergusson, H. C. 1988. "From the People Who Brought You Voodoo Economics: beyond entrepreneuralisation to US competitiveness" Harvard Business Review May 1988

Foray, D. 2014. "From smart specialisation to smart specialisation policy." European Journal of Innovation Management 17 (4): 492-507.

Ford, S.J., M. J. Routley, R. Phaal, and D. R. Probert. 2014. "The industrial emergence of commercial inkjet printing." European Journal of Innovation Management 17 (2): 126-143.

Friedman, H. H., T. Lopez-Pumarejo, and L. Weiser Friedman. 2007. "A new kind of marketing: creating micro-niches using resonance marketing." Journal of Internet Commerce 6 (1): 83-99.

Gaudes, A. 2004. "The skinny on being narrow: a longitudinal study on the influence of niche-width in the presence of market turbulence." Journal of Comparative International Management 7 (2): 12-30.

Geels, F.W. 2002. "Technological transitions as evolutionary reconfiguration processes: a multi-level perspective and a case-study." Research Policy 31 (8): 1257-1274.

Geels, F.W. 2004. "From sectoral systems of innovation to socio-technical systems. Insights about dynamics and change from sociology and institutional theory." Research Policy 33 (6): 897-920. 
Geels, F.W., and R. Raven. 2006. "Non-linearity and expectations in niche-development trajectories: ups and downs in Dutch biogas development (1973-2003).'Technology Analysis \& Strategic Management 18 (3/4): 375-392.

Geels, F.W., and R. Kemp. 2007. "Dynamics in socio-technical systems: typology of change processes and contrasting case studies." Technology in Society 29 (4): 441-455.

Geels, F.W., and J. Schot. 2007. "Typology of sociotechnical transition pathways." Research Policy 36: 399-417.

Genus, A., and A. M. Coles. 2006. "Firm strategies for risk management in innovation." International Journal of Innovation Management 10 (2): 113-126.

Georghiou, L., and K. Barker. 1993. "Management of international collaboration.” In New technologies and the firm, edited by P. Swann, 345-360. London: Routledge.

Gilfillan, S. C. 1935. The Sociology of Invention. Chicago: Follett Publishing Co.

Gray, C., and E. Gonsalves. 2002. "Organisational learning and entrepreneurial strategy." International Journal of Entrepreneurship and Innovation 3 (1): 27-33.

Gruber, M., I. C. MacMillan, and J. D. Thompson. 2008. "Look before you leap: market opportunity identification in emerging technology firms." Management Science 54 (9): $1652-1665$.

Haefiger, S., P. Jäger, and G. Krogh. 2010. „Under the radar: Industry entry by user entrepreneurs." Research Policy 39 (9): 1198-1213.

Hamlin, R., J. Henry, and R. Cuthbert. 2012. "Acquiring market flexibility via niche portfolios.” European Journal of Marketing 46 (10): 1302-1319.

Hardman, S., E. Shiu, and R. Steinberger-Wilckens. 2015. "Changing the fate of fuel cell vehicles: can lessons be learnt from Tesla Motors?" International Journal of Hydrogen Energy 40 (4): 1625-1638.

Harris, L. 1999. "Building Inter-Firm Networks: A Case Study of EMC SW Ltd. International." Journal of New Product Development and Innovation Management 1 (3): 211-218.

Harris, L., A. M. Coles, and K. Dickson. 2000. "Building innovation networks: issues of strategy and expertise." Technology Analysis and Strategic Management 12 (2): 229241. 
Hayter, C.S. 2015. "Social Networks and the Success of University Spin-offs: Toward an Agenda for Regional Growth.” Economic Development Quarterly 29 (1): 3-13.

Hayter, R., T. Barnes, and M. Bradshaw. 2003. "Relocating resource peripheries to the core of economic geography's theorizing." Area 35 (1): 15-23.

Henderson, R. 1995. "Of life cycles real and imaginary: The unexpectedly long old age of optical lithography." Research Policy 24 (4): 631-643.

Hermans, F., D. van Apeldoorn, M. Stuiver, and K. Kok. 2013. "Niches and networks: Explaining network evolution through niche formation processes."Research Policy 42 (3): 613-623.

Hezar, I., T. Dalgic, S. Phelan, and G. Knight. 2006. "Principles of global niche marketing strategies: An early conceptual framework." In Handbook of Niche Marketing, Principles and Practices, edited by T. Dalgic, 25-63. New York: The Haworth Press.

Hoffman, K., M. Parejo, J. Bessant, and L. Perren. 1998. "Small Firms, R \& D, Technology and Innovation: A UK Literature Review.’Technovation 18 (1): 39-55.

Hoogma, R., R. Kemp, J. Schot, and B. Truffer. 2002. Experimenting for sustainable transport. The approach of strategic niche management. London: Spoon Press.

Hooley, J. G., andJ. Saunders. 1993. Competitive Positioning: The Key to Market Success. London: Prentice-Hall.

Howells, J. 2002. "The response of old technology incumbents to technological competition-does the sailing ship effect exist?” Journal of Management Studies 39 (7): 887-906.

Hunt, R. A. 2013. "Entrepreneurial tweaking: An empirical study of technology diffusion through secondary inventions and design modifications by start-ups." European Journal of Innovation Management 16 (2): 148-170.

Ieromonachou, P., S. Potter, and M. Enoch. 2004. "Adapting strategic niche management for evaluating radical transport policies - the case of the Durham road access charging scheme.” International Journal of Transport Management 2 (2): 75-87. Jain, S. C. 2005. Marketing, Planning and Strategy. Florence: South-Western College Publishing. 
Jones-Evans, D., and F. Steward. 1995. "Technology, Entrepreneurship and the Small Firm." Proceedings of the European Conference on Technology Management University of Aston, Birmingham, July 5-7: 272-279.

Keegan, W., S. Moriarty, and T. Duncan. 1992. Marketing. Englewood-Cliffs: PrenticeHall.

Kemp, R., J. Schot, and R. Hoogma. 1998. "Regime shifts to sustainability through processes of niche formation: the approach of strategic niche management." Technology Analysis \& Strategic Management 10 (2): 175-195.

Klepper, S. 1997. "Industry life cycles.” Industrial and Corporate Change 6 (1): 145182.

Komninos, N., B. Musyck, and A. I. Reid. 2014. "Smart specialisation strategies in south Europe during crisis." European Journal of Innovation Management 17 (4): 448471.

Kotler, P. 2003. Marketing Management. New Jersey: Prentice Hall.

Kwon, T. 2012. "Strategic niche management of alternative fuel vehicles: A system dynamics model of the policy effect." Technological Forecasting \& Social Change 79 (9): 1672-1680.

Lai, K. -K., T. -S. Hung, M. -Y. Hsu, and W. T. Lin. 2011. "An innovative model of Blue Ocean Strategy and niche marketing in green industry: A case study of the smart LED industry." Proceedings of the PICMET: Portland International Center for Management of Engineering and Technology.

Laranja, L. 1998. "Entrepreneurial innovation networks: small firms' contribution to collective innovation Efforts," In New Technology Based Firms in the '90s, edited by W. During and R. Oakey, 62-70. London: Paul Chapman.

Landabaso, M. 2014. "Guest editorial on research and innovation strategies for smart specialisation in Europe." European Journal of Innovation Management 17 (4): 378389.

Levinthal, D. A. 1998. "The slow pace of rapid technological change: gradualism and punctuation in technological change." Industrial and Corporate Change 7 (2): 217-247. 
Lockwood, M. 2016. "Creating protective space for innovation in electricity distribution networks in Great Britain: The politics of institutional change." Environmental Innovation and Societal Transitions 18: 111-127

Lubik, S., E. Garnsey, and T. Minshall. 2012. "Beyond niche thinking: market selection in science-based ventures." Proceedings of Portland International Center for Management of Engineering and Technology: Technology Management for Emerging Technologies (PICMET12).

Maheshwari, B., A. George, and M. Maheshwari. 2011. "Establishing a market niche: The case of Keystrox."International Journal of Business and Globalisation 7 (4): 497509.

Marinova, D., and A. Balaguer. 2009. "Transformation in the photovoltaics industry in Australia, Germany and Japan: Comparison of actors, knowledge, institutions and markets." Renewable Energy 34 (2): 461-464.

Markard, J., R. Raven, and B. Truffer. 2012. "Sustainability transitions: an emerging field of research and its prospects." Research Policy 41 (6): 955-967.

Marvel, M.R., and S. Droege. 2010. "Prior tacit knowledge and first-year sales: learning from technology entrepreneurs." Journal of Small Business and Enterprise Development 17 (10): 32-44.

McGrath, M. E. 1995. Product strategy for high-technology companies. New York: Irwin.

Morone, P., V. E. Tartiu, and P. Falcone. 2015. "Assessing the potential of biowaste for bioplastics production through social network analysis." Journal of Cleaner Production 90: 43-54.

Namba, M. 2007. "Becoming a "global top niche company" through two-step innovation." Paper presented at the Portland International Conference on Management of Engineering and Technology, Portland, August 5-9.

Nokelainen, T., and O. Dedehayir. 2015. "Technological adoption and use after mass market displacement: The case of the LP record."Technovation 36: 65-76.

Oakey, R, A. Groen,G. Cook, and P. van der Sijde, eds. 2013. New Technology Based Firms in the New Millennium. Bingley: Emerald Group Publishing Ltd. 
Park, J. S. 2005. “Opportunity recognition and product innovation in entrepreneurial hitech start-ups: a new perspective and supporting case study." Technovation 25: 739-752. Pavitt, K. 1990. "What we know about the strategic management of technology." California Management Review 32 (3): 17-26.

Peng, Y.-N., and S. Walsh Sanderson. 2014. "Crossing the chasm with beacon products in the portable music player industry."Technovation 34: 77-92.

Peppal, L. 1992. "Strategic product choice and niche markets." Journal of Economics and Management Strategy 1 (2): 397-417.

Peters, S.R, and A. M. Coles. 2010. "Technological entrepreneurship and firm strategy: the development and commercialization of the Ballard fuel cell." International Journal of Entrepreneurship and Innovation 11 (1): 79-88.

Qian, S., and B. H. Kemelgor. 2013. "Boundaries of network ties in entrepreneurship: How large is too large?” Journal of Developmental Entrepreneurship18 (4): 246-257.

Rappert, B. 1997. "Links between universities and their spin-offs." Industry and Higher Education 12 (6): 332-338.

Raven, R. 2006. "Towards alternative trajectories? Reconfigurations in the Dutch energy regime.” Research Policy 35 (4): 581-595.

Raven, R. 2007a. "Co-evolution of waste and electricity regimes: Multi-regime dynamics in the Netherlands (1969-2003)."Energy Policy 35(4): 2197-2208.

Raven, R. 2007b. "Niche accumulation and hybridisation strategies in transition processes towards a sustainable energy system: An assessment of differences and pitfalls.” Energy Policy 35 (4): 2390-2400.

Raven, R.P.J.M., and F. W. Geels. 2010. "Socio-cognitive evolution in niche development: Comparative analysis of biogas development in Denmark and the Netherlands (1973-2004).’Technovation 30: 87-99.

Raven, R.P.J.M., E. Heiskanen, R. Lovio, M. Hodson, and B. Brohmann. 2008. "The contribution of local experiments and negotiation processes to field-level learning in emerging (niche) technologies.” Bulletin of Science, Technology \& Society 28 (6): 464477. 
Raven, R., and G. Verbong. 2004. "Ruling out innovations-technological regimes, rules and failures: the cases of heat pump power generation and bio-gas production in The Netherlands." Innovation: Management, Policy and Practice 6: 178-198.

Rudie Harrigan, K. 1980. "Strategies for declining industries." Journal of Business Strategy 1 (2): 20-34.

Runde, J., M. Jones, K. Munir, and L. Nikolychuk. 2009. “On technological objects and the adoption of technological product innovations: Rules, routines and the transition from analogue photography to digital imaging." Cambridge Journal of Economics 33 (1): $1-24$.

Said, M.F., K. A. Adham, N. A. Abdullah, S. F. Sarkam, F. Quoquab, and S. Hanninen. 2013. "Innovation and firm creation strategies in the emerging biotechnology industries.” International Journal of Economics and Management 7 (2): 348-375.

Schiavone, F. 2013. Communities of Practice and Vintage Innovation: A Strategic Reaction to Technological Change. Berlin: Springer Science \& Business Media.

Schiavone, F. 2014. "Innovation approaches for old products revitalisation after technological change: The rise of technology reverse." International Journal of Innovation Management 18 (2)

Schot, J. 1998. "The usefulness of evolutionary models for explaining innovation. The case of the Netherlands in the nineteenth century." History and Technology 14 (3): 173200.

Schot, J., and F. W. Geels. 2008. "Strategic niche management and sustainable innovation journeys: theory, findings, research agenda and policy." Technology Analysis \& Strategic Management 20 (5): 537-554.

Schot, J., and A. Rip. 1996. "The past and future of constructive technology assessment". Technological Forecasting and Social Change 54 (2): 251-268.

Sengers, F., Wieczorek, a. J., and Raven, R. (2016) "Experimenting for sustainability transitions: A systematic literature review". Technological Forecasting and Social Change, http://dx.doi.org/10.1016/j.techfore.2016.08.031

Seyfang, G., S. Hielscher, T. Hargreaves, M. Martiskainen, and A. Smith. 2014. "A grassroots sustainable energy niche? Reflections on community energy in the UK." Environmental Innovation and Societal Transitions 13: 21-44. 
Shove, E. 2012. "The shadowy side of innovation: unmaking and sustainability.’'Technology Analysis \& Strategic Management 24 (4): 363-375.

Sick, N., A. M. Nienaber, B. Liesenkötter, N. vom Stein, G. Schewe, and J. Leker.2016. "The legend about sailing ship effects-Is it true or false? The example of cleaner propulsion technologies diffusion in the automotive industry." Journal of Cleaner Production 137: 405-413.

Sidibé, A., S. Vellema, F. Dembelé, M. Traoré, and T. W. Kuyper. 2012. "Innovation processes navigated by women groups in the Malian shea sector: how targeting of international niche markets results in fragmentation and obstructs co-ordination." NJAS - Wageningen Journal of Life Sciences 60-63: 29-36.

Simba, A. 2015. "A new model of knowledge and innovative capability development for small born-global bio-tech firms: Evidence from the East Midlands, UK." International Journal of Entrepreneurship and Innovation Management 19(1/2): 30-58.

Simmie, J. 2012. "Path dependences and new technological path creation in the Danish wind power industry.” European Planning Studies 20 (5): 753-772.

Simon, H. 1996. Hidden champions: lessons from 500 of the world's best unknown companies. Boston: Harvard Business School Press.

Singh, G., and A. Prasad. 2014. "Innovation and entrepreneurial activities of SMEs in Fiji."International Journal of Entrepreneurship and Small Business 22(2): 251-265.

Smith, A. 2007. "Translating sustainabilities between green niches and socio-technical regimes." Technology Analysis \& Strategic Management 19 (4): 427-450.

Smith, A., F. Kern, R. Raven, and B. Verhees. 2014. "Spaces for sustainable innovation: Solar photovoltaic electricity in the UK." Technological Forecasting \& Social Change 81: 115-130.

Smith, A., and R. Raven. 2012. "What is protective space? Reconsidering niches in transitions to sustainability." Research Policy 41 (6): 1025-1036.

Smith, D. J. 2012. "Technological discontinuities, outsiders and social capital: a case study from Formula 1." European Journal of Innovation Management 15 (3): 332-350.

Smith, I. J., B. Tether, A. Thwaites, J. Townsend, and P. Wynarczyk. 1993. "The Performance of Innovative Small Firms: A Regional Issue." In New Technology and the Firm, edited by P. Swann, 54-82.London: Routledge. 
Snow, D. 2004. "Extraordinary efficiency growth in response to new technology entries: the carburettor's "last gasp"." Academy of Management Proceedings 1: K1-K6.

Snow, D. C., G. P. Pisano, E. Corsi, and G. U. Kristinsdottir. 2009. "Columbus Tubing: steel is real." Harvard Business School Case 609-042.

Srinivasan, R., G. L. Lilien, and A. Rangaswamy. 2006. "The emergence of dominant designs."Journal of Marketing 70 (2): 1-17.

Stritar, R., and M. Drnovšek. 2016. "What entrepreneurs discover when creating opportunities? Insights from Skype and YouTube ventures." International Entrepreneurship and Management Journal 12 (3): 659-679.

Sushandoyo, D., and T. Magnusson. 2014. "Strategic niche management from a business perspective: taking cleaner vehicles from prototype to series production." Journal of Cleaner Production 74: 17-26.

Tidd, J., J. Bessant, and K. Pavitt. 2001. Managing Innovation: Integrating Technological, Market and Organisational Change. Chichester: John Wiley and Sons.

Toften, K., and T. Hammervoll. 2009. "Niche firms and marketing strategy." European Journal of Marketing 43 (11/12): 1378-1391.

Toften, K., and T. Hammervoll. 2010. "Strategic orientation of niche firms." Journal of Research in Marketing and Entrepreneurship 12 (2): 108-121.

Unruh, G. C. 2000. “Understanding carbon lock-in.” Energy Policy 28: 817-830.

Utterback, J.M., and H. J. Acee. 2005. "Disruptive technologies: an expanded view." International Journal of Innovation Management 9 (1): 1-17.

Van de Belt, H., and A. Rip. 1987. "The Nelson-Winter/Dosi Model and synthetic dye chemistry." In Exploiting Technological Niches, edited by R. Hoogma. Twente: Twente University Press.

Van der Laak, W. W. M., R. P. J. M. Raven, and G. P. J. Verbong. 2007. "Strategic niche management for biofuels: Analysing past experiments for developing new biofuel policies.” Energy Policy 35 (6): 3213-3225.

Verbong, G., W. Christiaens, R. Raven, and A. Balkema. 2010. "Strategic Niche Management in an unstable regime: Biomass gasification in India." Environmental Science \& Policy 13(4): 272-281. 
Verhees, B., R. Raven, F. Veraart, A. Smith, and F. Kern. 2013. "The development of solar PV in the Netherlands: A case of survival in unfriendly contexts." Renewable and Sustainable Energy Reviews 19: 275-289.

Wang, M.-C., and M, -H. Chen. 2016. "The more, the better? The impact of closure collaboration network and network structures on technology-based new ventures' performance." $R$ \& D Management 46 (S1): 174-192.

Ward, W. H. 1967. "The sailing ship effect." Bulletin of the Institute of Physics and the Physical Society 18: 169.

Weber, M., R. Hoogma, B. Lane, and J. Schot. 1999.Experimenting with Sustainable Transport Innovations: A workbook for Strategic Niche Management. Seville: Institute for Prospective Technological Studies.

Windrum, P., and C. Birchenhall. 1998. „Is product life cycle theory a special case?

Dominant designs and the emergence of market niches through co-evolutionarylearning." Structural Change and Economic Dynamics 9 (1): 109-134.

Young, J.K., and N. S. Vonortas. 2014. "Managing risk in the formative years: Evidence from young enterprises in Europe.’Technovation 34: 454-465.

Word count: 8094 (excluding appendix)

\section{Appendix}

Table 1: A summary of case studies on different strategic niche management themes

\begin{tabular}{|l|l|l|}
\hline Theme & Case & Authors \\
\hline Historical empirical studies & $\begin{array}{l}\text { White lead and madder in } \\
19^{\text {th }} \text { century Netherlands }\end{array}$ & Schot (1998) \\
\cline { 2 - 3 } & Biofuels/biogas & $\begin{array}{l}\text { Geels and Raven (2006); } \\
\text { Raven and Geels (2010) }\end{array}$ \\
\hline
\end{tabular}




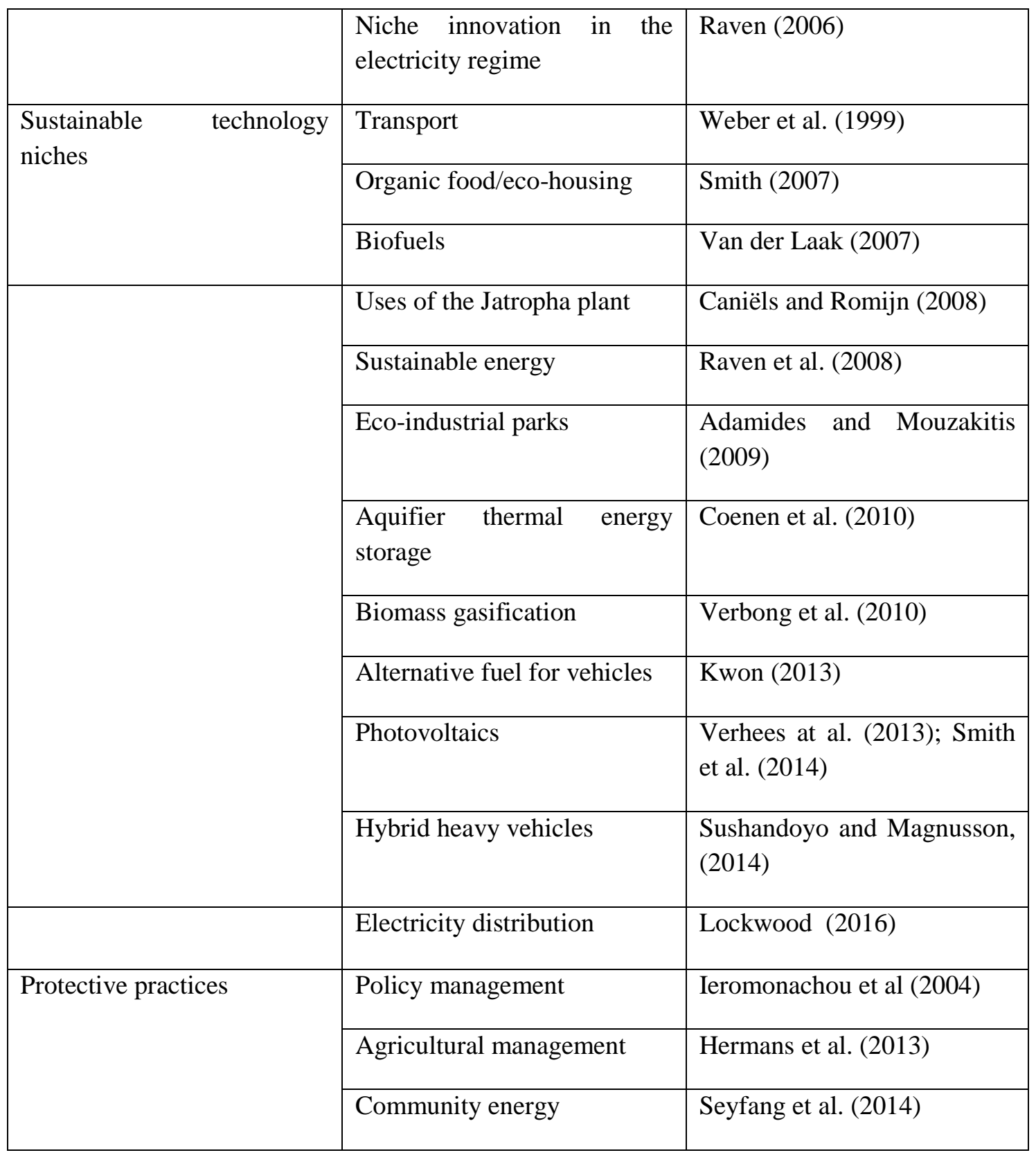

Table 2: Examples of niches and technologies in retreat

\begin{tabular}{|l|l|l|}
\hline Case & Strategic option & Authors \\
\hline $\begin{array}{l}\text { Piston Engines for private } \\
\text { aircrafts (Continental) }\end{array}$ & Retreat & Adner and Snow (2010b) \\
\hline $\begin{array}{l}\text { Magnetic-Tape-Drive } \\
\text { Technology (StorageTek) }\end{array}$ & Retreat & Adner and Snow (2010b) \\
\hline Leisure sailboat (Linjett) & Retreat & Adner and Snow (2010b) \\
\hline $\begin{array}{l}\text { Mechanical watches as luxury } \\
\text { niche }\end{array}$ & Retreat & Adner and Snow (2010a\&b) \\
\hline $\begin{array}{l}\text { Steel bicycle frames used in } \\
\text { touring bikes and pavement } \\
\text { roller tubes }\end{array}$ & Retreat and Repositioning & Snow et al. (2009) \\
\hline Cycling & Revitalisation & Shove (2012) \\
\hline
\end{tabular}




\begin{tabular}{|l|l|l|}
\hline Film scanners & Technology reverse & Schiavone (2014) \\
\hline $\begin{array}{l}\text { Analog Photography; radio } \\
\text { amateurs; arcade video } \\
\text { games; disc jockeys }\end{array}$ & Vintage innovation & Schiavone (2013) \\
\hline LP records & Revitalisation & $\begin{array}{l}\text { Nokelainen and Dedehayir } \\
(2015)\end{array}$ \\
\hline
\end{tabular}

